Педагогічного інституту

Киїського університету імені Бориса Грінченка

(Київ, Украӥна) o.venhlovska@kubg.edu.ua

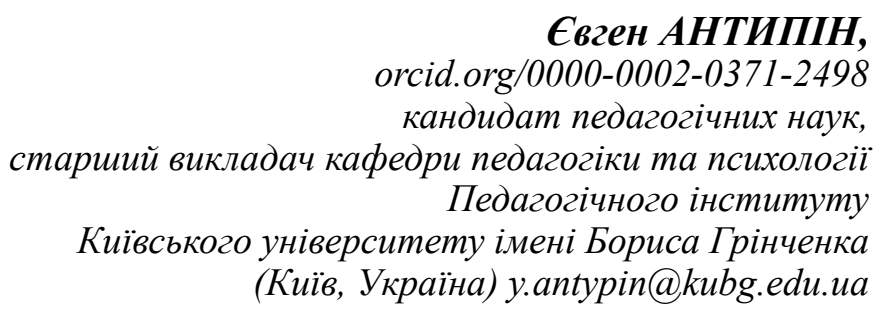

\title{
РЕТРОСПЕКТИВНИЙ ПОГЛЯД ЩОДО РЕАЛІЗАЦІЇ ІДЕЙ ДИТИНОЦЕНТРИЗМУ ВАСИЛЯ СУХОМЛИНСЬКОГО В НОВІЙ УКРАЇНСЬКІЙ ШКОЛІ
}

\begin{abstract}
У пропонованій розвідиі подано результати студіювання теоретичної та практичної спадщини Василя Сухомлинського з проблеми реалізаиї дитиночентричних ідей педагога в Новій українській школі. Мета дослідження полягала в розкритті сутнісної характеристики ідей дитиноиентризму Василя Сухомлинського для адаптації та застосування їх у практичі закладів дошкільної й загальної середньої освіти (початкова школа). Подано опис етапів розвитку ідей дитиночентризму в історико-педагогічному вимірі. 3'ясовано, щуо найбільш виразно вони реалізувалися в діяльності директора Павлиської середньої иколи В. Сухомлинського, щчо становило основу його педагогічної системи. Визначено сутність ичих ідей, яку педагог убачав у комплексі організаційних, психологопедагогічних, соиіокультурних умов, щзо становлять підгрунтя для формування ичілісної, гармонійної, творчої особистості. Вивчення праць педагога дало можливість з'ясувати складники ідей дитиноцентризму Василя Сухомлинського. До основних зараховано такі: гуманізм, повагу до особистості дитини, розвиток ї̈ індивідуальних та особистісних сенсів, створення в закладі освіти ситуації успіху, партнерство суб' єктів освітнього процесу. Установлено, щуо ідеї дитиноцентризму В. Сухомлинського є суголосні положенням Нової украӥнської школи. За результатами теоретичного пошуку охарактеризовано ключові компоненти змін, щчо відбуваються в Новій українській школі, з позиції їх реалізаџї В. Сухомлинським. Такими ключовими положеннями є виховання на цінностях, наскрізний процес виховання, педагогіка партнерства, вплив і значення природного, сочіокультурного середовища на формування нової генерації. Отже, досвід і рекомендаиії педагога щчодо реалізації ідей дитиноцентризму в закладах дошкільної освіти й початковій школі є значущиим, становлять як науковий, так і практичний інтерес.

Ключові слова: Василь Сухомлинський, дитиночентризм, гуманізм, наскрізний процес виховання, виховання на иінностях, педагогіка партнерства, заклади освіти.
\end{abstract}

Olena VENHLOVSKA, orcid.org/0000-0002-0456-7667

Candidate of Pedagogical Sciences, Associate Professor at the Department of Pedagogy and Psychology Pedagogical Institute of Borys Grinchenko Kyiv University (Kyiv, Ukraine) o.venhlovska@kubg.edu.ua

Yevhen ANTYPIN, orcid.org/0000-0002-0371-2498 Candidate of Pedagogical Sciences, Senior Lecturer at the Department of Pedagogy and Psychology Pedagogical Institute of Borys Grinchenko Kyiv University (Kyiv,Ukraine) y.antypin@kubg.edu.ua 


\title{
REALIZATION OF VASYL SUKHOMLYNSKY'S IDEAS OF CHILD-CENTEREDNESS IN THE NEW UKRAINIAN SCHOOL: A RETROSPECTIVE VIEW
}

\begin{abstract}
The proposed research presents the results of studying the theoretical and practical heritage of Vasyl Sukhomlynsky on the problem of implementing child-centered ideas of a teacher in the New Ukrainian School. The purpose of the study was to reveal the essential characteristics of the ideas of child-centeredness of Vasyl Sukhomlynsky for adaptation and their application in the practice of preschool and general secondary education (primary school). The article describes the stages of development of ideas of child-centeredness in the historical and pedagogical dimension. It was found out that they were most clearly realized in the activity of $V$. Sukhomlynsky, as a director of Pavlyska secondary school, which formed the basis of his pedagogical system. The essence of these ideas, which the teacher saw in the complex of organizational, psychological-pedagogical, socio-cultural conditions, which form the basis for the formation of a holistic, harmonious, creative personality, is determined. Studying the works of the teacher made it possible to find out the components of the ideas of child-centeredness of Vasyl Sukhomlynsky. The main ones are: humanism, respect for the child's personality, development of his individual and personal meanings, creation of a situation of success in the educational institution, partnership in the educational process. It is established that the ideas of child-centeredness of V. Sukhomlynsky are in agreement with the provisions of the New Ukrainian School. According to the results of the theoretical search, the key components of the changes taking place in the New Ukrainian School from the standpoint of their implementation by $V$. Sukhomlynsky are characterized. Such key provisions are: education on values, cross-cutting process of education, pedagogy of partnership, the impact and importance of the natural, socio-cultural environment on the formation of a new generation. Therefore, the experience and recommendations of the teacher on the implementation of the ideas of childcenteredness in preschool and primary schools are significant and are of both scientific and practical interest.

Key words: Vasyl Sukhomlynsky, child-centeredness, humanism, end-to-end process of education, education on values, pedagogy of partnership, educational institutions.
\end{abstract}

Постановка проблеми. Реформування системи освіти в Україні відбувається з орієнтацією на врахуванням потреб, можливостей, здібностей здобувачів освіти. Згідно 3 положеннями Концепції Нової української школи, пріоритетним у проєктуванні освітнього середовища в закладах освіти $є$ принцип дитиноцентризму, що спрямований на реалізацію індивідуальної освітньої траєкторії дітей. Студіювання джерельної бази засвідчує, що в українській педагогічній думці накопичено значний досвід щодо реалізації ідей дитиноцентризму в освітній практиці. Значний інтерес для вивчення становить реалізація означених вище ідей у теоретико-практичній спадщині Василя Сухомлинського, що були домінувальними в діяльності педагога. Погляди Василя Сухомлинського щодо місії школи у створенні умов для розвитку особистості дитини є суголосні тим, що декларує Нова українська школа, а отже, вони потребують нового прочитання й реалізації в освітньому просторі України.

Аналіз досліджень. Дослідження проблеми реалізації дитиноцентричних ідей Василя Сухомлинського в освітньому процесі закладів освіти України здійснювалося за результатами теоретичного аналізу джерельної бази. Відбір і класифікація джерел відбувалися 3 урахуванням підходів, що розроблені сучасними вченими в галузі історії педагогіки (Л. Березівська, Н. Дічек, Н. Гупан, Г. Іванюк, О. Сухомлинська, Є. Хриков). Джерельну базу дослідження становлять наукові студії українських учених, у яких висвітлено кон- цептуальні положення ідей дитиноцентризму, інтерпретаційні (монографії, наукові статті) джерела, тематику яких спрямовано на висвітлення особливостей реалізації Василем Сухомлинським виокремлених ідей у руслі освітніх змін, першоджерела (праці В. Сухомлинського) використано задля розуміння реалізації означеного феномена в освітній практиці Павлиської середньої школи.

Вивчення праць засвідчило, що питання дитиноцентризму були предметом наукових дискусій українських учених. Студіювання грунтовної джерельної бази виявило, що теоретичні підходи до розвитку цього поняття розкрито в дослідженнях О. Квас (Квас, 2012), В. Кременя (Кремень, 2009).

У наукових розвідках $€$. Антипіна (Антипін, 2015), Л. Баліки (Баліка, 2019), О. Венгловської (Венгловська, 2016) висвітлено особливості розвитку та реалізації ідей дитиноцентризму в практиці європейських та українських педагогів-сподвижників кінця XIX - першої половини XX століття.

3 огляду на предмет дослідження, значний інтерес становлять публікації, що розглядають різні аспекти педагогіки дитиноцентризму В. Сухомлинського (Богуш, 2018; Карпенко, 2015; Ярославцева, 2015), вартісними є напрацювання науковців щодо обгрунтування педагогом системи 3 «уведення дитини у світ людинознавства» (Іванюк, 2018а: 161) та актуалізації педагогіки В. Сухомлинського в контексті розбудови Нової української школи (Іванюк, 2018b), реалізації в роботі $з$ дітьми аксіологічного складника творчості педагога (Савченко, 2017). 
Автори цих публікацій підходять до прочитання ідей дитиноцентризму Василя Сухомлинського $з$ позицій особистісно орієнтованої освітньої парадигми, обгрунтовують концептуальні положення цих ідей (ціннісний вимір дитинства, повага до особистості дитини, іiі унікальність і неповторність, створення гуманного середовища закладу освіти, наскрізний процес виховання) та можливі шляхи їх адаптації в сучасний освітній процес закладів дошкільної та загальної середньої освіти.

Вивчення першоджерел «Серце віддаю дітям» (Сухомлинський, 2012), «Павлиська середня школа» (Сухомлинський, 1977, Т. 4), «Як любити дітей», «Людина неповторна», «Педагогіка серця» (Сухомлинський, 1977, Т. 5) тощо дало можливість з'ясувати, що питання сутності педагогіки дитиноцентризму В. Сухомлинським розкрито крізь призму взаємозв'язків, що формуються в природному, соціальному, культурному середовищах, системного підходу до реалізації дитячих потреб та інтересів, цілісності навчально-виховного (освітнього) процесу в закладі освіти.

В умовах розбудови Нової української школи актуалізується потреба студіювання продуктивних ідей дитиноцентризму, зреалізованих у педагогічній практиці Василем Сухомлинським, a тому метою статті $\epsilon$ здійснення ретроспективного погляду педагога щодо розкриття сутності ідей дитиноцентризму, що можуть бути адаптовані в освітні практики закладів дошкільної та загальної середньої освіти (початкова школа).

Досягнення визначеної мети забезпечено комплексом взаємопов'язаних методів дослідження: а) загальнонаукових - аналіз, синтез, систематизація, узагальнення, порівняння - сприяли відбору й систематизації джерельної бази, з'ясуванню сутності ключового поняття розвідки; б) біографічного, що уможливив вивчення спадщини В. Сухомлинського щодо впровадження ним ідей дитиноценризму в практику Павлиської середньої школи; в) історико-системного, що дав можливість комплексно підійти до висвітлення проблематики дослідження з позиції іiі суголосності вимогам Нової української школи.

Виклад основного матеріалу. У дослідженнях науковців поняття дитиноцентризму розглядається в контексті аксіологічного підходу: пріоритету цінності дитини й періоду дитинства загалом.

Вивчення історико-педагогічних джерел дало можливість з' ясувати еволюцію та сутність поняття «дитиноцентризм». З'ясовано, що розвиток ідей дитиноцентризму характерний для західноєвро- пейської педагогіки кінця XIX - початку XX століття, що відбувався в контексті реформаторської педагогіки. Ї̈і представники (А. Біне, О. Декролі, Дж. Дьюї, Е. Кей, М. Монтессорі, Ф. Фребель) проголошували дитину найвищою цінністю. У цей період набули поширення продуктивні, практико орієнтовані форми та методи роботи, що забезпечували розвиток творчих здібностей дітей, ураховували їхні потреби й інтереси.

В Україні в хронологічних межах кінця $\mathrm{XIX}$ - першої третини XX століття прихильниками такого підходу були Б. Грінченко, О. Дорошенко, Н. Лубенець, Т. Лубенець, С. Русова, Я. Чепіга та ін., які розбудовувати українську освіту з урахуванням західноєвропейських тенденцій щодо формування особистості дитини, антропоцентричного, діяльнісного, аксіологічного підходів.

У радянську добу в навчально-виховному процесі дитячих садків і початкових шкіл домінувала нормативно-знаннєва парадигма, сутність якої полягала в стандартизації вимог до підготовки підростаючого покоління, у формуванні колективу, а не індивідуальності, а відтак ідеї дитиноцентризму були дещо нівельовані.

Відродження та нового звучання означені вище ідеї набули в діяльності педагогів-новаторів: Ш. Амонашвілі, О. Захаренка, I. Ткаченка, В. Сухомлинського, які в умовах лібералізації суспільного життя на цих ідеях розробляли авторські освітні системи, домінувальними в яких були нонконформістський складник, індивідуальність $і$ неповторність кожної дитини.

3 отриманням Україною незалежності (1991), коли в освіті відбувався відхід від нормативнознаннєвого підходу, досвід саме цих педагогів став основоположним у розробленні особистісно орієнтованої освітньої парадигми, підгрунтям якої став дитиноцентризм.

3 огляду на предмет пропонованої розвідки, значущими для студіювання $є$ ідеї дитиноцентризму, що розвинув у діяльності директор Павлиської середньої школи В. Сухомлинський. Вивчення теоретичної та практичної спадщини педагога сприяло виокремленню сутності поняття «дитиноцентризм». Під цим поняттям педагог убачав комплекс організаційних, психолого-педагогічних, соціокультурних умов, що були визначальними у формуванні цілісної, гармонійної, творчої особистості. Вивчення теоретичної бази дало можливість 3'ясувати, що ключовими положеннями педагогіки дитиноцентризму Василя Сухомлинського є гуманізм, повага до особистості дитини, розвиток ії індивідуальних та особистісних можливостей, створення в закладі 
освіти ситуації успіху, партнерство суб'єктів освітнього процесу.

У Концепції Нової української школи визначено ii основні компоненти. 3-поміж дев'яти компонентів, які становлять формулу Нової української школи, варто виокремити три, що були важливими в діяльності В. Сухомлинського та спрямовувалися на формування гармонійної особистості. До них зараховуємо «наскрізний процес виховання, який формує цінності, педагогіку, що грунтується на партнерстві між учителем, учнями і батьками, орієнтацію на потреби учня в освітньому процесі, дитиноцентризм, сучасне освітне середовище, що забезпечить необхідні умови, засоби і технології для навчання учнів, освітян, батьків не лише в приміщенні навчального закладу» (Концепція Нової української школи: 07).

Проаналізуємо виокремлені положення з позиції трактування їх сутності В. Сухомлинським. Нова стратегія підготовки молодої генерації грунтується на гуманізмі та повазі до особистості дитини. Саме вони є фундаментом змін, що відбуваються в дошкільній і початковій освіті. Ці два складники червоною ниткою проходять крізь усю теоретико-практичну спадщину В. Сухомлинського. У низці статей «Педагогіка серця», «Обережно: дитина!», «Людина - найвища цінність» (Сухомлинський, 1977, Т. 5) педагог виокремлює думку, що формування гармонійної, цілісної особистості відбувається за умови визнання дитини найвищою цінністю. А отже, пріоритетним для закладів освіти, на думку педагога, мали стати повага честі й гідності дитини, забезпечення ii1 права на щастя, реалізація власних здібностей, можливостей, інтересів.

Діяльність Павлиської середньої школи з-поміж інших шкіл того часу вирізняв наскрізний, орієнтований на провідні дитиноцентричні цінності процес виховання, вибудуваний $з$ урахуванням єдності навчання, праці, пошуково-дослідницької діяльності. У перебігу організації різних форм залучення учнів до пізнання навколишнього світу, засвоєння ними практичного досвіду реалізувалися завдання формування гармонійної особистості. Ціннісний концепт виховання та навчання полягав у формуванні загальнолюдських, громадянських, суспільнозначущих цінностей, моральних (духовних) чеснот дитини.

В. Сухомлинський був переконаний, що для успішного введення дітей у світ цінностей необхідно гуманізувати навчально-виховне середовище школи, щоб у закладі домінувала атмосфера людяності. Людиноцентризм, на думку педагога, становить основу формування ціннісної сфери дитини. У праці «Серце віддаю дітям» педагог зазначав: «Виховання - то $є$ насамперед людинознавство, людинознання. Без знання психіки дитини - iї розумового розвитку, мислення, зацікавленості, захоплень, здібностей, задатків, нахилів - немає виховання» (Сухомлинський, 2012: 45). Отже, щоб процес виховання в закладі освіти мав наскрізний характер, вихователю чи/ або вчителю необхідно знати й розуміти сутність дитини, створити умови для повноцінного проживання дитиною періоду дитинства, адже «від того, як минуло дитинство, хто вів дитину за руку в дитячі роки, що ввійшло в іiі розум і серце 3 навколишнього світу - від цього вирішальною мірою залежить, якою людиною стане сьогоднішній малюк» (Сухомлинський, 2012: 49).

Реалізація наскрізного процесу виховання можлива за умови співпраці дітей, педагогів і батьків. Педагогіка партнерства була домінувальною в діяльності В. Сухомлинського. Педагогом обгрунтовано систему співпраці закладу освіти 3 батьками, розроблено рекомендації для педагогів і батьків щодо визначення спільних векторів у формуванні особистості.

В умовах упровадження Новою українською школою педагогіки партнерства значущим для переосмислення та адаптації є досвід Василя Олександровича щодо організації педагогізації батьків, залучення їх до співпраці. Педагог був переконаний, що ефективна співпраця в тріаді «учні - батьки - педагоги» сприяє виробленню спільних стратегій і цінностей щодо формування особистості. Педагогічний колектив i батьки мають гуртуватися навколо вирішення питань, що спрямовані на визначення векторів щодо реалізації молодим поколінням власних здібностей, потреб, інтересів. Підгрунтям педагогіки партнерства В. Сухомлинського були повага, довіра, відповідальність, співпраця між суб'єктами навчально-виховного процесу.

Гідною уваги для нинішніх педагогів є співпраця школи і батьків, що розпочиналася в Павлиській школі задовго до вступу дитини до школи. На базі середньої школи в с. Павлиш функціонувала школа для батьків, мета якої полягала у вивищенні педагогічної культури батьків щодо різних питань виховання. Тут зародився прогресивний для тих років досвід: слухачів школи (батьків) розподіляли за віковими категоріями їхніх дітей. Такий підхід сприяв усвідомленому вирішенню питань, що становили інтерес для батьків у чітко визначений проміжок часу. Заслуговують на увагу форми взаємодії педагогів і батьків, що здійсню- 
валися в межах роботи школи. Це була інтеграція теоретичної та практичної підготовки, у перебігу якої обговорювалися питання, актуальні для кожної окремо взятої родини.

3 огляду на те що педагогіка партнерства $€$ пріоритетною в розбудові Нової української школи, прогресивними для врахування $\epsilon$ педагогічні умови іiі реалізації, що обгрунтовані В. Сухомлинським. До основних зараховуємо такі:

- проєктування співпраці між учнями, батьками та педагогами на принципах гуманізму й індивідуального підходу;

- розуміння суб'єктами освітнього процесу місії та візії педагогічного партнерства;

- варіативність у виборі форм, методів партнерства 3 урахуванням індивідуальних потреб сімей щодо виховання особистості;

- психологічну, педагогічну готовність суб'єктів освітнього процесу до педагогічного партнерства.

3 огляду на актуальність проблематики статті, ми акцентуємо увагу на ідеї В. Сухомлинського про вплив середовища на розвиток і становлення особистості. На думку педагога, фізичний, психологічний, інтелектуальний розвиток дитини забезпечується цілим комплексом чинників середовища. Завдання вчителя (вихователя) полягає як у створенні оптимального розвивального середовища в закладі освіти, так і в максимальному використанні виховного впливу навколишнього середовища (природного, культурного, соціального).

Таку інтеграцію природного та соціокультурного середовищ яскраво представлено в «Школі радості» В. Сухомлинського. Педагог довів, що формування мислення дітей відбувається в процесі безпосередньої іiї взаємодії з навколишнім, оскільки вона (дитина) «мислить образами» (Сухомлинський, 1977: 80). Розвивальний потенціал природи створює оптимальні умови для навчання учнів у перебігу пошуково-дослідницької діяльності із застосуванням проблемного, діяльнісного підходів. Настанови та рекомендації, що розроблені педагогом, нині набувають нового звучання й утілюються педагогами в практику закладів дошкільної та загальної середньої освіти України, оскільки звернення до природного й соціокультурного середовищ формує в дітей дошкільного та молодшого шкільного віку творче мислення, уміння вчитися, досліджувати процеси й явища, робити припущення, установлювати причинно-наслідкові зв'язки, робити висновки.

Висновки. Отже, вивчення теоретико-практичного доробку В. Сухомлинського щодо реалізації ідей дитиноцентризму в закладі дошкільної освіти й початковій школі дає можливість для виокремлення таких висновків.

Ідеї дитиноцентризму становлять основу авторської освітньої системи В. Сухомлинського. Реалізуючи їх, педагог розробляв концепції щодо формування творчого мислення школярів, взаємозалежності й взаємовпливу природного та соціокультурного середовищ на особистість дитини, використання практико орієнтованих, пошуководослідницьких, проблемних методів навчання, партнерства навчальних закладів із батьками вихованців задля реалізації індивідуальної траєкторії формування особистості дитини.

Ми поділяємо виосновування педагога, що ідеї дитиноцентризму є життєдайними й дієвими лише за умови, якщо всі суб'єкти освітнього процесу, середовище навчального закладу за пріоритет ставлять необхідність вивчення сутності дитини, iї потреб, інтересів, створення умов для реалізації вихованцями та учнями особистісних запитів щодо розвитку, віри у власні можливості.

Публікації В. Сухомлинського потребують нового прочитання, переосмислення й утілення в освітній процес закладів дошкільної освіти та Нової української школи, оскільки містять прогресивний досвід щодо розв'язання тих викликів, які стоять перед сучасною школою.

У підсумку зазначимо, що зміст пропонованої розвідки не претендує на розкриття всіх концептів заявленої проблеми. Предметом подальших наукових досліджень можуть бути питання 3'ясування впливу ідей В. Сухомлинського на подальший розвиток шкільної практики.

\section{СПИСОК ВИКОРИСТАНИХ ДЖЕРЕЛ}

1. Антипін Є. Б. Ідеї дитиноцентризму в педагогічних поглядах Тимофія Лубенця. Педагогічні науки: теорія, історія, інноваиійні технології. 2015. № 2. С. 79-85.

2. Баліка Л. Творче використання ідей дитиноцентризму Януша Корчака в системі освіти України. Інноватика у вихованні. 2019. Вип. 9. С. 90-100.

3. Богуш А. Дитиноцентризм Василя Сухомлинського в педагогічному вимірі століття. Науковий вісник МНУ імені В. О. Сухомлинського. Серія «Педагогічні науки». 2018. № 3 (62). С. 17-21.

4. Венгловська О. А. Розвиток ідей дитиноцентризму в педагогічній думці України (кінець XIX - 20-ті pp. XX століття). Theoretical and applied researches in the field of pedagogy, psychology and social sciences : Conference Proceedings, December 28-29, 2016. Kielce : Holy Cross University, 2016. C. 41-43. 
5. Іванюк Г. І. Новаторство в школах України у другій половині ХХ століття: соціально-педагогічний феномен. Pedagogical and psychological sciences: development prospects in countries of Europe at the beginning of the third millennium : Collective monograph. Volume 2. Riga : Izdevnieciba «Baltija Publishing», 2018a. C. 158-175.

6. Іванюк Г. І. Новаторські ідеї Василя Сухомлинського в контексті розбудови Нової української школи. Наукові записки Центральноукраїнського державного педагогічного університету імені Володимира Винниченка. Серія «Педагогічні науки». 2018b. Випуск 171. С. 49-54.

7. Карпенко О. Є. Ідея дитиноцентризму у спадщині Василя Сухомлинського. Педагогічна освіта: теорія $i$ практика. 2015. Вип. 18. С. 41-46.

8. Квас О. Дитиноцентризм - педагогіка дитини як humanum. Iсторико-педагогічний альманах. 2012. № 1. URL: http://ipa.udpu.edu.ua/issue/view/815.

9. Кремень В. Г. Про «Дитиноцентризм», або Чому освіта України потребує структурних змін. День : щзоденна всеукраӥнська газета. 2009. № 210 (3130). 19 листопада. С. 1-6.

10. Нова українська школа: Концептуальні засади реформування середньої школи, ухвалені Рішенням Колегії МОН України 27.10.2016 / за заг. ред. М. Грищенка. Київ. 2016, 34 с. URL: https://mon.gov.ua/storage/app/media/ zagalna\%20serednya/nova-ukrainska-shkola-compressed.pdf (дата звернення: 12.09.2020).

11. Савченко О. Аксіологічні смисли літературної спадщини Василя Сухомлинського: філософія для дітей. Рідна школа. 2017. № 9/10. С. 44-48.

12. Сухомлинський В. Серце віддаю дітям. Харків : Акта, 2012. 537 с.

13. Сухомлинський В. О. Людина - найвища цінність. Вибрані твори : у 5 т. Київ, 1977. Т. 5. С. 446-472.

14. Сухомлинський В. О. Людина неповторна. Вибрані твори : у 5 т. Київ, 1977. Т. 5. С. 80-96.

15. Сухомлинський В. О. Обережно дитина! Вибрані твори : у 5 т. Київ, 1977. Т. 5. С. $422-426$.

16. Сухомлинський В. О. Павлиська середня школа. Вибрані твори : у 5 т. Київ, 1977. Т. 4. С. 7-390.

17. Сухомлинський В. О. Педагогіка серця. Вибрані твори : у 5 т. Київ, 1977. Т. 5. С. 316-321.

18. Сухомлинський В. О. Як любити дітей. Вибрані твори : у 5 т. Київ, 1977. Т. 5. С. 292-308.

19. Ярославцева Л. Я. Ідеї дитиноцентризму в педагогічній системі В. О. Сухомлинського. Педагогічні науки: теорія, історія, інноваційні технології. 2015. № 2(46). С. 181-188.

\section{REFERENCES}

1. Antypin Ye. B. Idei dytynotsentryzmu v pedahohichnykh pohliadakh Tymofiia Lubentsia [Ideas of child-centeredness in the pedagogical views of Tymofiy Lubents]. Pedahohichni nauky: teoriia, istoriia, innovatsiini tekhnolohii. 2015 . № 2. S. 79-85 [in Ukrainian].

2. Balika L. Tvorche vykorystannia idei dytynotsentryzmu Yanusha Korchaka v systemi osvity Ukrainy [Creative use of Janusz Korczak's ideas of child-centeredness in the education system of Ukraine]. Innovatyka u vykhovanni. 2019. Vyp. 9. S. 90-100. DOI 10.35619/iiu.v0i9.128 [in Ukrainian].

3. Bohush A. Dytynotsentryzm Vasylia Sukhomlynskoho v pedahohichnomu vymiri stolittia [Vasyl Sukhomlynsky's child-centeredness in the pedagogical dimension of the century]. Naukovyi visnyk MNU imeni V. O. Sukhomlynskoho. Seriia: Pedahohichni nauky. 2018. № 3(62). S. 17-21 [in Ukrainian].

4. Venhlovska O. A. Rozvytok idei dytynotsentryzmu v pedahohichnii dumtsi Ukrainy (kinets XIX - 20-ti rr. XX stolittia) [Development of ideas of child-centeredness in the pedagogical thought of Ukraine (end of the XIX - 20s of the XX century)]. International Scientific-Practical Conference «Theoretical and applied researches in the field of pedagogy, psychology and social sciences»: Conference Proceedings, December 28-29, 2016. Kielce: Holy Cross University. S. 41-43 [in Ukrainian].

5. Ivaniuk H. I. Novatorstvo v shkolakh Ukrainy u druhii polovyni KhKh stolittia: sotsialno-pedahohichnyi fenomen [Innovation in schools of Ukraine in the second half of the twentieth century: a socio-pedagogical phenomenon]. Pedagogical and psychological sciences: development prospects in countries of Europe at the beginning of the third millennium: Collective monograph. Volume 2. Riga : Izdevnieciba «Baltija Publishing», 2018a. S. 158-175 [in Ukrainian].

6. Ivaniuk H. I. Novatorski idei Vasylia Sukhomlynskoho v konteksti rozbudovy Novoi ukrainskoi shkoly [Innovative ideas of Vasyl Sukhomlynsky in the context of building the New Ukrainian School]. Naukovi zapysky Tsentralnoukrainskoho derzhavnoho pedahohichnoho universytetu imeni Volodymyra Vynnychenka. Seriia: Pedahohichni nauky. 2018b.Vypusk 171. S. 49-54 [in Ukrainian].

7. Karpenko O. Ye. Ideia dytynotsentryzmu u spadshchyni Vasylia Sukhomlynskoho [The idea of child-centeredness in the legacy of Vasyl Sukhomlynsky]. Pedahohichna osvita: teoriia i praktyka. 2015. Vyp. 18. S. 41-46 [in Ukrainian].

8. Kvas O. Dytynotsentryzm - pedahohika dytyny yak humanum [Child-centeredness is the pedagogy of the child as humanum]. Istoryko-pedahohichnyi almanakh. 2012. № 1. URL: http://ipa.udpu.edu.ua/issue/view/815 [in Ukrainian].

9. Kremen V. H. Pro «Dytynotsentryzm», abo Chomu osvita Ukrainy potrebuie strukturnykh zmin [About «Childcenteredness», or Why education in Ukraine needs structural changes]. Shchodenna vseukrainska hazeta «Den». 2009. № 210 (3130). 19 lystopada. S. 1-6 [in Ukrainian].

10. Nova ukrainska shkola: Kontseptualni zasady reformuvannia serednoi shkoly [The new Ukrainian school: Conceptual principles of secondary school reform] / Ukhvalenyi rishenniam Kolehii MON 27.10.2016 / za zah. red. Hryshchenko Mykhailo. Kyiv. 2016, 34 s [in Ukrainian].

11. Savchenko O. Aksiolohichni smysly literaturnoi spadshchyny Vasylia Sukhomlynskoho: filosofiia dlia ditei [Axiological meanings of Vasyl Sukhomlynsky's literary heritage: philosophy for children]. Ridna shkola. 2017. № 9/10. S. 44-48 [in Ukrainian]. 
12. Sukhomlynskyi V. Sertse viddaiu ditiam [I give my heart to children]. Kharkiv: Akta, 2012. $537 \mathrm{~s}$ [in Ukrainian].

13. Sukhomlynskyi V. O. Liudyna - naivyshcha tsinnist [Man is the highest value]. Vybrani tvory: u 5-ty t. Kyiv, 1977. T. 5. S. 446-472 [in Ukrainian].

14. Sukhomlynskyi V. O. Liudyna nepovtorna [The man is unique]. Vybrani tvory: u 5-ty t. Kyiv, 1977. T. 5. S. 80-96 [in Ukrainian].

15. Sukhomlynskyi V. O. Oberezhno dytyna! [Be careful baby!]. Vybrani tvory: u 5-ty t. Kyiv, 1977. T. 5. S. $422-426$ [in Ukrainian].

16. Sukhomlynskyi V. O. Pavlyska serednia shkola [Pavliska High School]. Vybrani tvory: u 5-ty t. Kyiv, 1977. T. 4. S. 7-390 [in Ukrainian].

17. Sukhomlynskyi V. O. Pedahohika sertsia [Pedagogy of the heart]. Vybrani tvory: u 5-ty t. Kyiv, 1977. T. 5. S. 316-321 [in Ukrainian].

18. Sukhomlynskyi V. O. Yak liubyty ditei [How to love children]. Vybrani tvory: u 5-ty t. Kyiv, 1977. T. 5. S. 292-308 [in Ukrainian].

19. Yaroslavtseva L. Ya. Idei dytynotsentryzmu v pedahohichnii systemi V. O. Sukhomlynskoho [Ideas of childcenteredness in the pedagogical system of V.O. Sukhomlinsky]. Pedahohichni nauky: teoriia, istoriia, innovatsiini tekhnolohii. 2015. № 2(46). S. 181-188 [in Ukrainian]. 